\title{
Analisis Pengaruh Faktor Kebutuhan Energi Listrik Tahun 2015 Terhadap Daya Yang Tersambung Dan Energi Yang Terjual Menggunakan Regresi Linear Sederhana (Studi Kasus Pada PT. PLN (Persero) Unit Area Pelayanan Dan Jaringan (APJ) Palembang)
}

\author{
Nazori Suhandi $^{1)}$, Irma Yuliawati ${ }^{2)}$, Indah Charista ${ }^{3)}$ \\ ${ }^{12) 3)}$ Program Studi Teknik Informatika Universitas Indo Global Mandiri \\ Jln. Jend. Sudirman No. 629 KM. 4 Palembang, Kode pos : 30129 \\ Email: Nazori@uigm.ac.id ${ }^{1}$, almagigit@gmail.com ${ }^{2}$, indahcha13@gmail.com $^{3}$
}

\begin{abstract}
The availability of electrical energy is a very important aspect and even become a parameter to support the successful development of a region. Proper management of electrical energy resources and directed clearly will make the potential possessed of an area developed and utilized optimally. Population growth and economic development of a region can be influenced by the use of electrical energy. The supply of electricity must be taken into account so that the electrical energy can be available in an amount that suits your needs. Demand for the use of electricity in Indonesia will always increase with economic growth in addition to the development of electrical energy is also influenced by the development of the population in terms of quantity of customers to be electricity. Predicting methods such as using time series method (Gustriansyah, 2017) or data mining methods. The purpose of this research is to know how to overcome the influence of electricity usage (VA) connected with electric energy sold (KWh). Research done by simple linear regression method to facilitate writer in processing data. Based on the calculation result using simple linear regression method can be concluded $99.2 \%$ of the variation of electric power connected can be explained by the variable amount of electrical energy sold. While the rest $(100 \%-99.2 \%=0.8 \%)$ is explained by other causes. And the level of significance $<0.05$ so that the regression model can be used to predict the electrical energy sold.
\end{abstract}

Keywords : Linear regression, analysis, electrical energy

\begin{abstract}
Abstrak
Ketersediaan energi listrik merupakan aspek yang sangat penting dan bahkan menjadi suatu parameter untuk mendukung keberhasilan pembangunan suatu daerah. Pengelolaan sumber daya energi listrik yang tepat dan terarah dengan jelas akan menjadikan potensi yang dimiliki suatu wilayah berkembang dan termanfaatkan secara optimal. Pertumbuhan populasi dan perkembangan ekonomi suatu wilayah dapat dipengaruhi penggunaan energi listrik. Penyediaan listrik harus diperhitungkan sehingga energi listrik dapat tersedia dalam jumlah yang sesuai dengan kebutuhan Anda. Permintaan untuk penggunaan energi listrik di Indonesia akan selalu meningkat dengan pertumbuhan ekonomi disamping pengembangan energi listrik juga dipengaruhi oleh perkembangan populasi dalam hal kuantitas pelanggan yang akan dialiri listrik. Metode untuk memprediksi seperti menggunakan metode time series (Gustriansyah, 2017) atau metode data mining. Adapun tujuan dari penelitian ini adalah untuk mengetahui bagaimana cara mengatasi pengaruh penggunaan tenaga listrik (VA) yang terhubung dengan energi listrik yang terjual (KWh). Penelitian dilakukan dengan metode regresi linier sederhana agar memudahkan penulis dalam mengolah data. Berdasarkan hasil perhitungan menggunakan metode regresi linier sederhana dapat disimpulkan sebesar 99,2\% dari variasi daya listrik yang terhubung dapat dijelaskan oleh variabel jumlah energi listrik yang terjual. Sedangkan sisanya $(100 \%-99,2 \%=$ $0,8 \%$ ) dijelaskan oleh penyebab lain. Dan tingkat signifikansi <0,05 sehingga model regresi dapat digunakan untuk memprediksi energi listrik yang terjual.
\end{abstract}

Kata kunci: Regresi linier, analisis, energi listrik 


\section{Pendahuluan}

Ketersediaan energi listrik merupakan aspek yang sangat penting dan bahkan menjadi suatu parameter untuk mendukung keberhasilan pembangunan suatu daerah. Pengelolaan sumber daya energi listrik yang tepat dan terarah dengan jelas akan menjadikan potensi yang dimiliki suatu wilayah berkembang dan termanfaatkan secara optimal.

Permintaan akan penggunaan energi listrik di Indonesia akan selalu meningkat sesuai dengan pertumbuhan ekonomi selain itu perkembangan energi listrik juga dipengaruhi oleh perkembangan penduduk dalam pengertian jumlah pelanggan yang akan dialiri listrik. Untuk memenuhi permintaan kebutuhan energi listrik tersebut harus diantisipasi sedini mungkin agar penyediaan energi listrik dapat tersedia dalam jumlah yang cukup dan harga yang memadai.

Penelitian ini akan mengkaji bagaimana dampak daya listrik yang tersambung (VA) dengan Energi yang terjual (KWh) pada PT. PLN (Persero) Unit Area Pelayanan dan Jaringan (APJ) Palembang sebagai studi kasus dengan menggunakan model regresi linier.

Persamaan regresi merupakan suatu persamaan formal untuk mengekspresikan 2 (dua) unsur penting dari suatu hubungan statistik. Regresi digunakan untuk memenuhi 2 tujuan yaitu menentukan pola antara variabel yang ada dan memprediksi atau menentukan nilai suatu variabel.

Regresi mengukur seberapa besar suatu variabel mempengaruhi variabel yang lain, sehingga dapat digunakan untuk melakukan peramalan nilai suatu variabel berdasarkan variabel lain.

Dalam analisis regresi ada dua jenis variabel, yaitu variabel penjelas (explanatory variable) atau variabel bebas (independent variable) dan variabel respons (respons variable) atau variabel tidak bebas (dependent variable). Yang dimaksud dengan variabel penjelas adalah suatu variabel yang nilainya dapat ditentukan atau dengan mudah dapat diukur. Sedangkan variabel respons adalah suatu variabel yang nilainya sukar ditentukan atau tidak mudah diukur. Variabel penjelas biasa disimbolkan dengan $\mathrm{X}$ dan disebut sebagai variabel yang mempengaruhi. Sedangkan variabel respons biasa disimbolkan dengan $\mathrm{Y}$ dan disebut sebagai variabel yang dipengaruhi. Analisis regresi digunakan pada kedua variabel tersebut terutama untuk menelusuri pola hubungan yang modelnya belum diketahui dengan sempurna.

Analisis regresi adalah suatu analisis statistik yang memanfaatkan hubungan antara dua variabel atau lebih yaitu variabel Y (variabel dependen atau respons) pada beberapa variabel lain $\mathrm{X} 1, \mathrm{X} 2, \ldots, \mathrm{Xk}$, (variabel independent atau predictor). Dimana $\mathrm{X}$ diasumsikan mempengaruhi $\mathrm{Y}$ secara linear. Jika analisis regresi dilakukan untuk satu variabel dependen dan satu variabel independent maka regresi ini dinamakan regresi sederhana. Analisis regresi linear diperoleh dari suatu motivasi bahwa plot data variabel $\mathrm{X}$ (pengaruh) dan $\mathrm{Y}$ (respons) cenderung linear.

\section{Pembahasan}

Pertumbuhan penduduk dan perkembangan ekonomi suatu daerah dapat mempengaruhi penggunaan energi listrik. Penyediaan energi listrik harus diperhitungkan sehingga energi listrik dapat tersedia dalam jumlah sesuai dengan kebutuhan. Permintaan akan penggunaan energi listrik di Indonesia akan selalu meningkat sesuai dengan pertumbuhan ekonomi selain itu perkembangan energi listrik juga dipengaruhi oleh perkembangan penduduk dalam pengertian jumlah pelanggan yang akan dialiri listrik. Oleh karena itu, untuk penelitian selanjutnya diharapkan dapat mencari tahu faktor-faktor apa saja yang dapat mempengaruhi daya listrik yang tersambungMenguraikan hasil penelitian analisis kualitatif, kuantitatif, Penelitian R\&B dengan penekanan pada jawaban atas permasalahan.

Metodelogi yang digunakan pada penelitian ini yaitu dengan menggunakan regresi linear sederhana. Metode ini digunakan untuk melihat hubungan antara perubahan daya tersambung dengan energi terjual pada unit PT. PLN (Persero) Unit Area Pelayanan dan Jaringan (APJ) Palembang.

Objek penelitian yang digunakan pada penelitian ini adalah energi listrik tahun 2015 pada PT. PLN (Persero) Unit Area Pelayanan dan Jaringan (APJ) Palembang.

Metode yang digunakan untuk mengumpulkan data yaitu dari survey data terhadap instansi atau badan yang menyediakan data yang dibutuhkan sepertiBPS (Badan Pusat Statistik) dan PLN (Perusahaan Listrik Negara). Data yang didapatkan dari BPS berupa data jumlah penduduk dan rumah tangga. Dan data yang didapatkan dari PLN berupa data pengusahaan listrik yang terdiri dari data pengusahaan berupa energi terjual dan daya tersambung.

Adapun tahapan penelitian dapat dilihat pada Gambar 1 berikut ini :

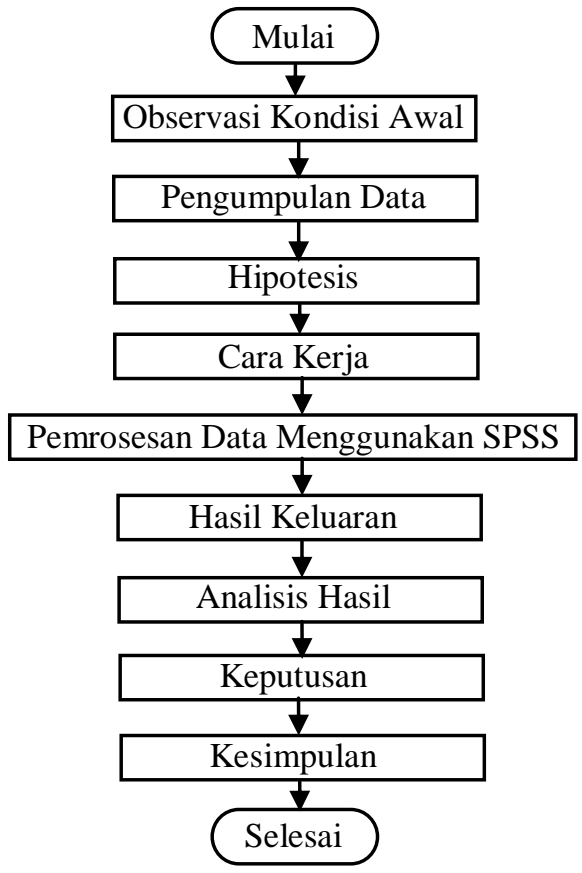

Gambar 1. Tahapan Penelitian 
Berdasarkan tahapan penelitian di atas, maka dapat dilihat bahwa langkah awal dari penelitian adalah melakukan observasi terhadap objek yang akan dilakukan penelitian. Setelah itu dilakukan pengumpulan data dan menghasilkan hipotesis. Kemudian memproses data dengan menggunakan SPSS, sehingga adanya hasil keluaran. Selanjutnya menganalisis outputnya seberapa besar sebuah variabel mempengaruhi variabel lain. Kemudian keputusan dari keluaran dianalisis apakah model regresi dapat digunakan untuk melakukan prediksi atau tidak. Selanjutnya apakah data dari analisis keluaran tersebut sudah bersifat normal. Langkah yang terakhir adalah memberikan kesimpulan kepada objek penelitian.

\section{A. Pengumpulan Data}

Data kelistrikan dikumpulkan/diperoleh dari statistik ketenagalistrikan berupa data mentah. Data mentah yang diperoleh disini adalah data pengusahaan energi listrik yang didapat dari Direktorat Jenderal Ketenagalistrikan. Data pengusahaan energi listrik ini meliputi pemakaian energi listrik dari setiap sektor untuk APJ Palembang selama 1(satu) tahun yaitu tahun 2015 (Tabel 1-3).

Tabel 1. Data Energi Terjual (KWh) Pengusahaan Energi Listrik per Sektor APJ Palembang Tahun 2015

\begin{tabular}{|c|c|r|}
\hline No. & Sektor & Tahun 2015 \\
\hline 1. & Rumah Tangga & $2.832,17$ \\
\hline 2. & Industri & 751,18 \\
\hline 3. & Usaha & 796,92 \\
\hline 4. & Sosial & 146,02 \\
\hline 5. & Gedung kantor pemerintah & 92,18 \\
\hline 6. & Penerangan jalan umum & 119,01 \\
\hline
\end{tabular}

Tabel 2. Data Daya Tersambung (VA) Pengusahaan Energi Listrik per Sektor APJ Palembang Tahun 2015

\begin{tabular}{|c|c|r|}
\hline No. & Sektor & Tahun 2015 \\
\hline 1. & Rumah Tangga & $1.674,24$ \\
\hline 2. & Industri & 304,56 \\
\hline 3. & Usaha & 437,75 \\
\hline 4. & Sosial & 95,16 \\
\hline 5. & Gedung kantor pemerintah & 70,90 \\
\hline 6. & Penerangan jalan umum & 28,79 \\
\hline
\end{tabular}

Tabel 3. Jumlah Pelanggan APJ Palembang Tahun 2015

\begin{tabular}{|c|c|r|}
\hline No. & Sektor & Tahun 2015 \\
\hline 1. & Rumah Tangga & 1.746 .804 \\
\hline 2. & Industri & 598 \\
\hline 3. & Usaha & 63.267 \\
\hline 4. & Sosial & 30.234 \\
\hline 5. & Gedung kantor pemerintah & 6.203 \\
\hline 6. & Penerangan jalan umum & 4.658 \\
\hline
\end{tabular}

B. Hipotesis

1. Uji Korelasi

$\mathrm{H}_{0}$ : Tidak ada hubungan (korelasi) antara Daya Tersambung dengan Energi Terjual.

$\mathrm{H}_{\mathrm{a}}$ : Terdapat hubungan (korelasi) negatif antara Daya Tersambung dengan Energi Terjual, karena semakin tinggi Daya Tersambung semakin rendah Energi Terjual.

Maka dalam penelitian ini dilakukan Uji Satu Sisi (1-Tailed) yakni ke sisi kiri karena hubungannya negatif.

Tingkat Probabilitas : $\mathrm{p}=95 \%$

Kriteria pengujian :

Nilai signifikansi > 0,05 $\mathrm{H}_{0}$ diterima. Artinya tidak terdapat hubungan (korelasi) antar variabel.

Nilai signifikansi $<0,05 \mathrm{H}_{0}$ ditolak. Artinya terdapat hubungan (korelasi) negatif antar variabel.

\section{Uji Regresi Linear}

$\mathrm{H}_{0}$ : Model regresi tidak bisa digunakan untuk melakukan sebuah prediksi.

$\mathrm{H}_{\mathrm{a}}$ : Model regresi bisa digunakan untuk melakukan sebuah prediksi.

Tingkat Probabilitas : $\mathrm{p}=95 \%$.

Kriteria pengujian :

Nilai signifikansi $>0,05, \mathrm{H}_{0}$ diterima maka model regresi tidak bisa digunakan untuk melakukan prediksi.

Nilai signifikansi $<0,05, \mathrm{H}_{0}$ ditolak maka model regresi bisa digunakan untuk melakukan prediksi.

\section{Cara Kerja}

Gambar 2 hingga Gambar 11 merupakan penjelasan pengolahan data dengan SPSS.

a. Inputkan variabel angka energi terjual dan daya tersambung Variable View, kemudian inputkan data ke dalam tabel-tabel pada data view.

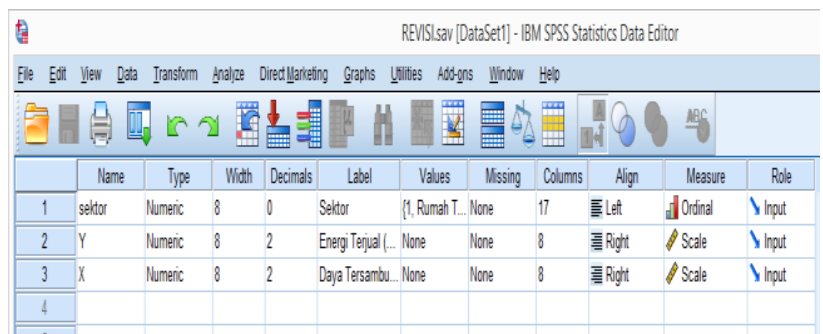

Gambar 2. Input Variabel

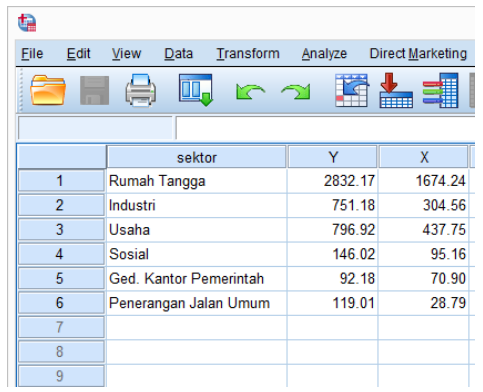

Gambar 3. Data View 
b. Pilih menu Analyze $\rightarrow$ Corelate $\rightarrow$ Bivariate (untuk uji korelasi)

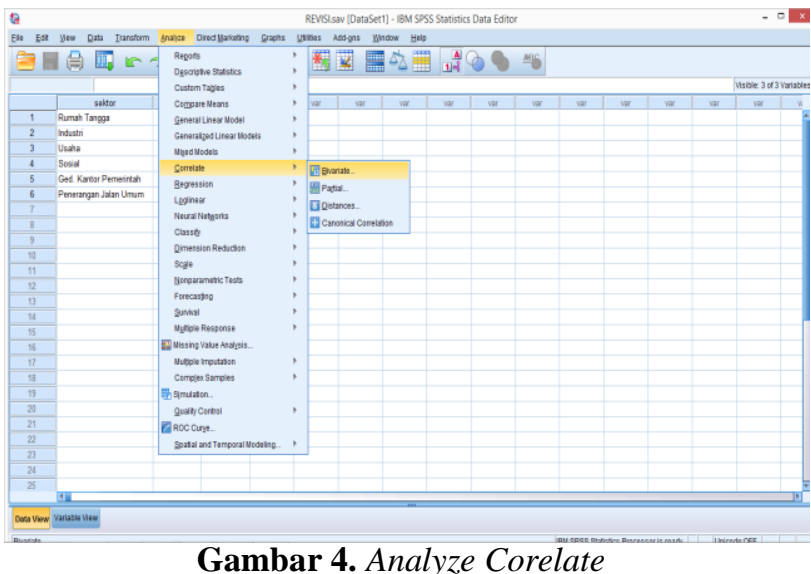

c. Masukkan variabel energi terjual dan daya tersambung kepada kolom sebelah kanan yang bertuliskan Variables. Checklist Pearson, one tailed and $\mathrm{Ok}$.

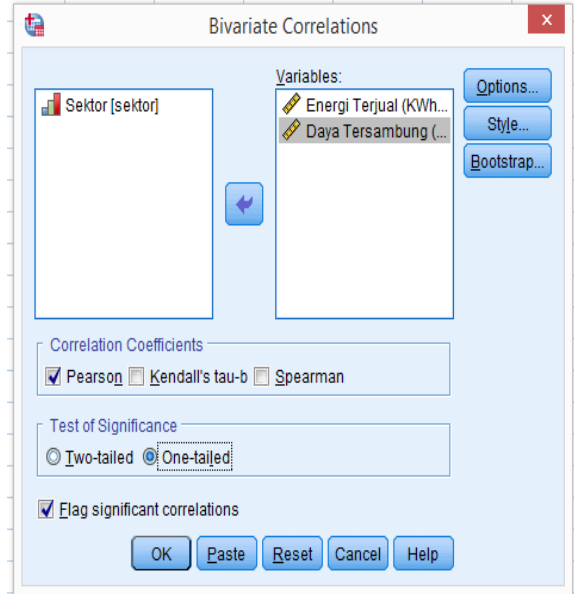

Gambar 5. Checklist Pearson, one tailed and $\mathrm{Ok}$

d. Pilih menu Analyze $\rightarrow$ Regression $\rightarrow$ Linear (untuk uji regresi secara linear).

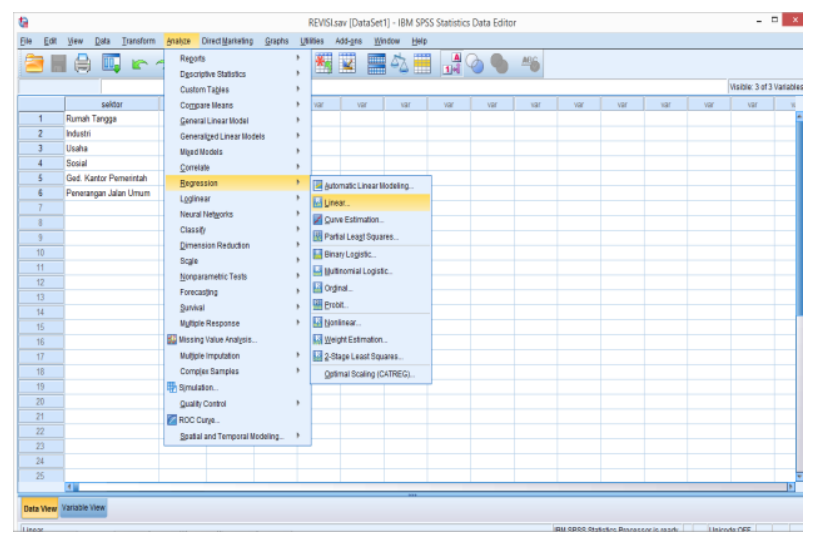

Gambar 6. Analyze Regression e. Masukkan variabel energi terjual ke dalam Dependent dan masukkan daya tersambung ke dalam kolom Independent.

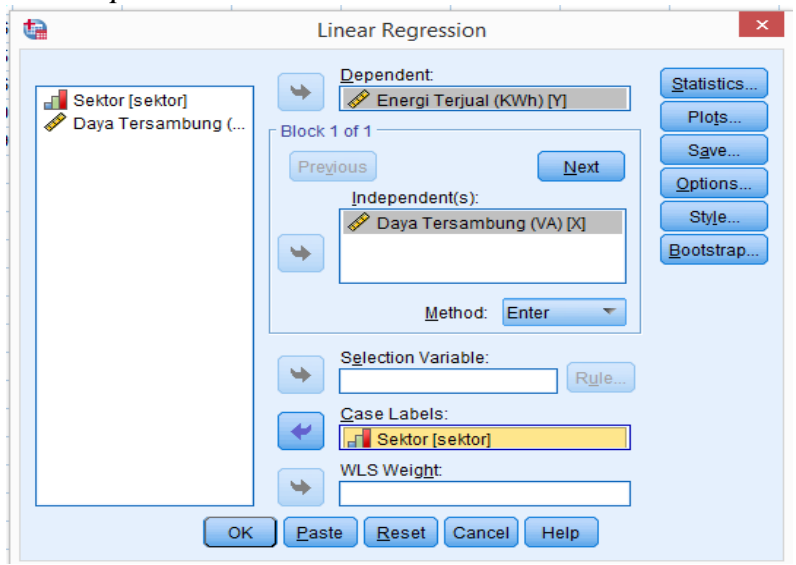

Gambar 7. Linear Regression

f. Pilih kolom option. Isi nilai probabilitas sesuai dengan yang diinginkan $(0,05)$. Checklist include constant in equation dan exclude cases listwise.

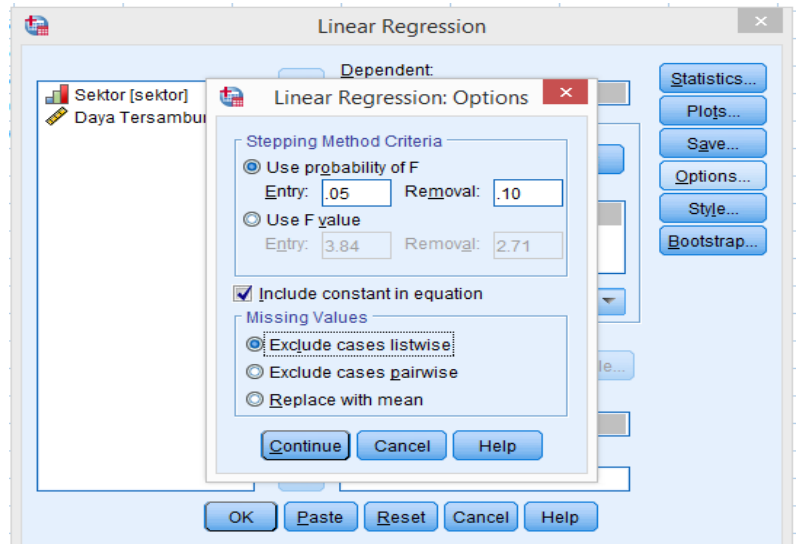

Gambar 8. Linear Regression "Option”

g. Pilih kolom statistics. Checklist estimates, model fit, dan casewise diagnostics serta pilih All cases.

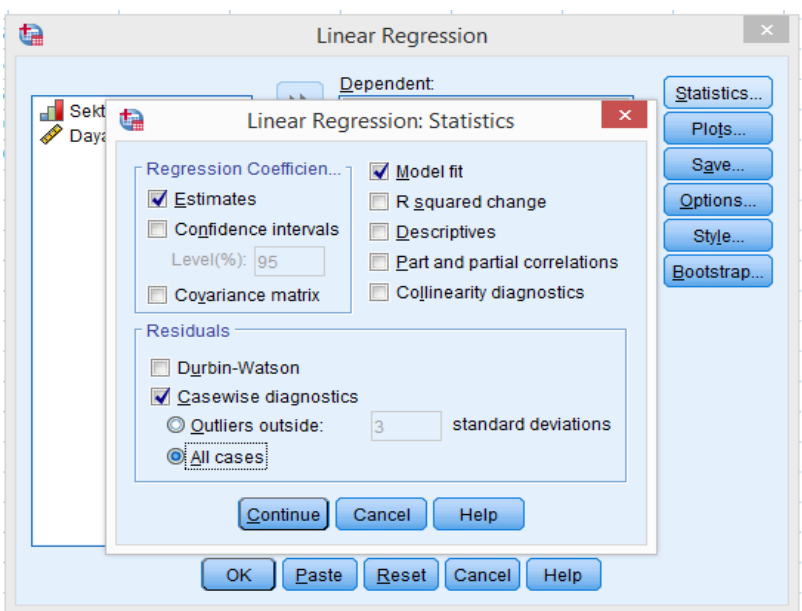

Gambar 9. Linear Regression "Statistic" 
h. Pilih kolom plots. Masukkan SDRESID ke dalam kolom Y dan ZPRED ke dalam kolom X. pilih next, kemudian masukkan ZPRED ke dalam kolom Y dan DEPENDENT ke dalam kolom X. Checklist normality probability plot.

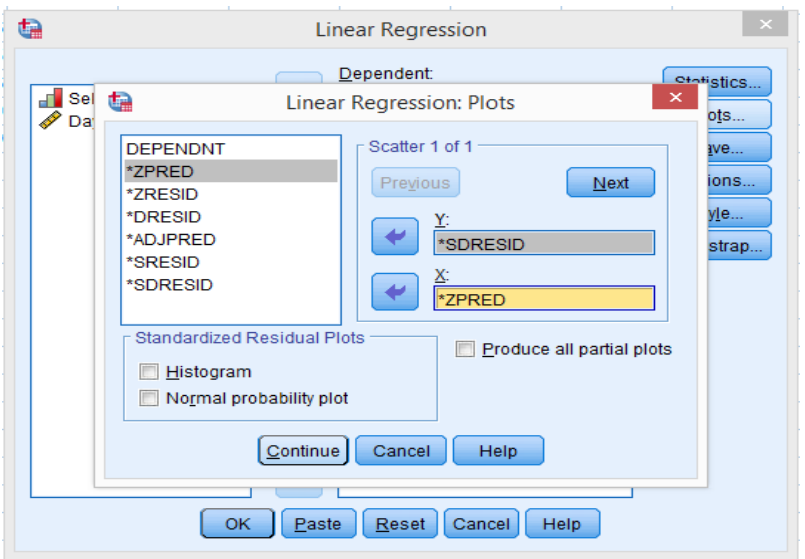

Gambar 10. Linear Regression "plots 1 ”

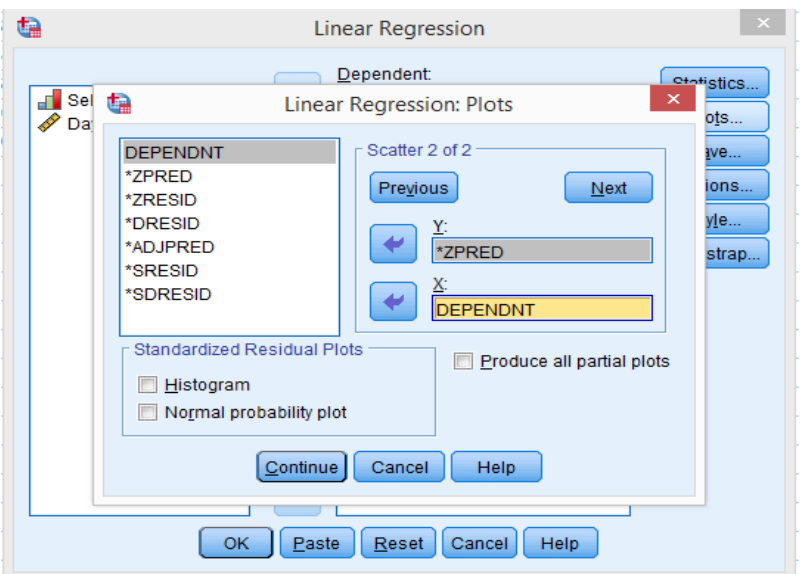

Gambar 11. Linear Regression "plots 2”

i. Tekan OK untuk proses data.

\section{Pemrosesan Data dan Hasil Keluaran}

Data yang telah diperoleh akan diproses/diuji korelasi dan regresi linearnya menggunakan aplikasi statistik SPSS.

\section{Uji Korelasi}

Tabel 4 berikut menunjukkan hasil uji korelasi:

Tabel 4. Correlations

\begin{tabular}{|ll|r|r|}
\hline & $\begin{array}{r}\text { Energi } \\
\text { Terjual } \\
\text { (KWh) }\end{array}$ & $\begin{array}{c}\text { Daya } \\
\text { Tersambung } \\
\text { (VA) }\end{array}$ \\
\hline \begin{tabular}{ll|r} 
Energi \\
Terjual \\
(KWh)
\end{tabular} & $\begin{array}{l}\text { Pearson } \\
\text { Correlation }\end{array}$ & 1 & $.996^{* * *}$ \\
& Sig. (1-tailed) & & .000 \\
\hline $\begin{array}{l}\text { Daya } \\
\begin{array}{l}\text { Tersambung } \\
\text { (VA) }\end{array}\end{array}$ & $\begin{array}{l}\text { Pearson } \\
\text { Correlation }\end{array}$ & $.996^{* *}$ & 1 \\
\hline
\end{tabular}

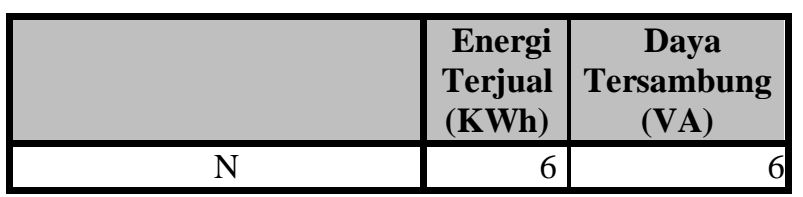

**. Correlation is significant at the 0.01 level (1tailed).

2. Uji Regresi Linear

Tabel 5-7 dan Gamba 12 berikut adalah hasil keluaran uji regresi linear:

Tabel 5. Keluaran 1 "Model Summary"

\begin{tabular}{|c|c|c|c|c|}
\hline Model & $\mathbf{R}$ & $\begin{array}{c}\mathbf{R} \\
\text { Square }\end{array}$ & $\begin{array}{c}\text { Adjusted } \\
\text { R Square }\end{array}$ & $\begin{array}{c}\text { Std. Error } \\
\text { of the Estimate }\end{array}$ \\
\hline 1 & $.996^{\mathrm{a}}$ & .992 & .989 & 108.11217 \\
\hline
\end{tabular}

a. Predictors: (Constant), Daya Tersambung (VA)

b. Dependent Variable: Energi Terjual (KWh)

Tabel 6. Keluaran 2 "ANOVA"

\begin{tabular}{|c|c|c|c|c|c|}
\hline Model & $\begin{array}{c}\text { Sum of } \\
\text { Squares }\end{array}$ & d & $\begin{array}{c}\text { Mean } \\
\text { Square }\end{array}$ & $\mathbf{F}$ & $\begin{array}{c}\text { Sig } \\
.\end{array}$ \\
\hline $\begin{array}{l}1 \text { Regressi } \\
\text { on }\end{array}$ & 5477149.738 & 1 & $\begin{array}{c}5477149.7 \\
38\end{array}$ & $\begin{array}{c}468.6 \\
3\end{array}$ & $\begin{array}{c}.000 \\
\mathrm{~b}\end{array}$ \\
\hline Residual & 46752.964 & 4 & 11688.241 & & \\
\hline Total & 5523902.702 & J & & & \\
\hline
\end{tabular}

a. Dependent Variable: Energi Terjual (KWh)

b. Predictors: (Constant), Daya Tersambung (VA)

Tabel 7. Keluaran 3 "Coefficients ${ }^{a}$ ",

\begin{tabular}{|l|r|r|r|c|}
\hline \multirow{2}{*}{ Model } & \multicolumn{2}{|c|}{$\begin{array}{c}\text { Unstd } \\
\text { Coefficients }\end{array}$} & \multicolumn{1}{c|}{$\begin{array}{c}\text { Std } \\
\text { Coefficients }\end{array}$} & \multirow{2}{*}{ t } \\
\cline { 2 - 4 } & \multicolumn{1}{|c|}{ B } & $\begin{array}{c}\text { Std. } \\
\text { Error }\end{array}$ & \multicolumn{1}{|c|}{ Beta } & \\
\hline $\begin{array}{l}\text { 1(Constant) } \\
\begin{array}{l}\text { Daya } \\
\text { Tersambung } \\
\text { (VA) }\end{array}\end{array}$ & 63.091 & 55.447 & & 1.138 \\
\hline
\end{tabular}

a. Dependent Variable: Energi Terjual (KWh)

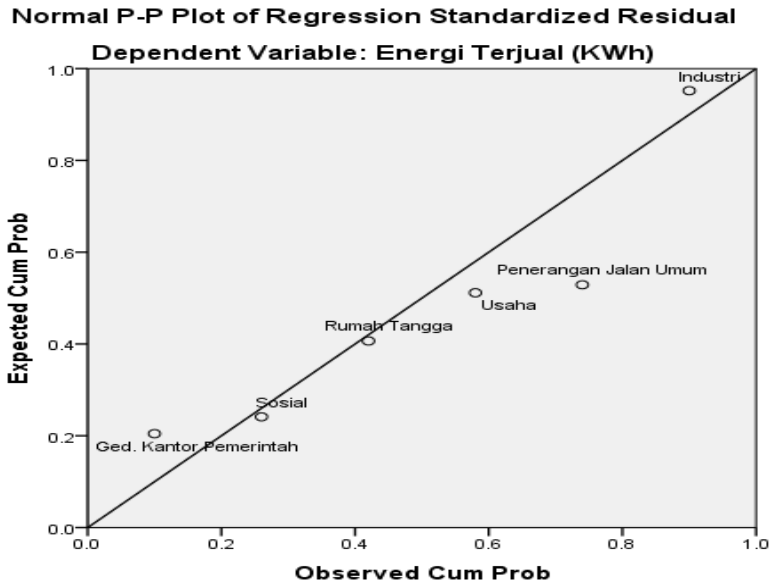

Gambar 12. Keluaran 4 "Normal Probability Plot" 


\section{Analisa Hasil}

1. Keluaran Uji Korelasi

Berdasarkan hasil keluaran pada Tabel 4 dapat dianalisis bahwa korelasi pada variabel daya tersambung dengan angka jumlah energi terjual diperoleh angka probabilitas atau sig. (1-tailed) sebesar 0,000

\section{Keluaran Uji Regresi Linear}

Keluaran 1 "Model Summary" pada Tabel 5 menunjukkan nilai $\mathrm{R}$ yang merupakan penjelas seberapa besar sebuah variabel mempengaruhi variabel lainnya. Angka R square pada keluaran 1 adalah 0,992 yang merupakan pengkuadratan dai koefisien korelasi. $\mathrm{R}$ square bisa disebut koefisien determinasi $\left(\mathrm{R}^{2}\right)$ dimana hal itu berarti $99,2 \%$ dari variasi daya tersambung bisa dijelaskan oleh variabel energi terjual.

Sementara sisanya $0,8 \%$ dijelaskan oleh sebab lain. $\mathrm{R}$ square berkisar pada angka 0 sampai 1, dengan catatan semakin kecil angka R Square maka semakin lemah hubungan kedua variabel.

Tabel 6 menunjukkan apakah sebuah model regresi bisa digunakan untuk melakukan sebuah prediksi atau tidak. Dari uji ANOVA atau F Test di atas, diperoleh F hitung sebesar 468,603 dengan tingkat signifikansi 0,000 .

Tabel 7 memperlihatkan persamaan regresi yang muncul untuk daya tersambung (VA) dan energi terjual (KWh) seperti pada persamaan (1) berikut.

$$
\mathrm{Y}=63,091+(1,669) \mathrm{X}
$$

Dimana $\mathrm{Y}=$ Jumlah energi terjual dan $\mathrm{X}=$ presentase daya tersambung.

Keluaran 4 "Chart" pada Gambar 12 merupakan Normal Probability Plot yang menunjukkan apakah uji normalitas data yang digunakan sudah terpenuhi atau belum. Terlihat bahwa sebaran data pada Chart di atas bisa dikatakan tersebar di sekeliling garis lurus tersebut (tidak terpencar jauh dari garis lurus).

\section{E. Keputusan}

1. Uji Korelasi

Karena memiliki nilai sig. (1-tailed) $<0,05$ maka $\mathrm{H}_{0}$ ditolak, sehingga terdapat hubungan negatif antara daya tersambung dengan energi terjual.

\section{Uji Regresi Linear}

Keluaran 1, sebesar 99,2\% dari variasi daya listrik yang tersambung bisa dijelaskan oleh variabel angka energi listrik yang terjual. Sementara sisanya $0,8 \%$ dijelaskan oleh sebab lain.

Keluaran 2, tingkat signifikansi $<0,05$ maka model regresi bisa digunakan untuk memprediksi enegi listrik yang terjual.

Keluaran 3, persamaan regresi yang muncul untuk kenaikan daya tersambung dan angka energi terjual.

$$
\mathrm{Y}=63,091+(1,669) \mathrm{X}
$$

Dimana $\mathrm{Y}=$ jumlah energi terjual dan $\mathrm{X}=$ presentase daya tersambung. Persebaran data tidak terpencar jauh maka dapat dikatakan bahwa persyaratan normalitas bisa dipenuhi.

\section{Kesimpulan}

Berdasarkan hasil perhitungan dengan menggunakan metode regresi linear sederhana dapat ditarik kesimpulan yaitu sebesar 99,2\% dari variasi daya listrik yang tersambung bisa dijelaskan oleh variabel angka energi listrik yang terjual. Sementara sisanya $0,8 \%$ dijelaskan oleh sebab lain, dan tingkat signfikansi $<0,05$ maka model regresi linier bisa digunakan untuk memprediksi energi listrik yang terjual.

Hasil dari penelitian ini adalah informasi yang menunjukkan adanya hubungan antara data perusahaan energi listrik dengan jumlah pelanggannya, yang nantinya bisa ditarik kesimpulan bahwa model regresi linier dapat digunakan untuk memprediksi energi listrik yang terjual.

Penelitian selanjutnya diharapkan dapat menerapkan berbagai metode untuk memprediksi seperti menggunakan metode time series (Gustriansyah, 2017) atau metode data mining (Gustriansyah, 2017). Selain itu, perlu juga diteliti faktor-faktor apa saja yang dapat mempengaruhi daya listrik yang tersambung selain energi listrik yang terjual. Apabila PT. PLN (Persero) ingin menaikkan harga daya listrik yang tersambung, PT. PLN (Persero) harus meneliti dahulu apa saja faktorfaktor yang dapat mempengaruhi jumlah energi listrik yang terjual sehingga energi terjual dapat semakin ditekan.

\section{Daftar Pustaka}

Azhar, M. F. 2016. Azuharu Another Dream. Diambil kembali dari Perbedaan Regresi dan Korelasi : http://azuharu.net/statistik/perbedaan-regresi-dankorelasi/

Direktorat Jenderal Ketenagalistrikan. 2015. Statistik Ketenagalistrikan 2015 (Edisi No. 29 Tahun Anggaran 2016). (Online), (https://www.scribd.com/mobile/document/34681992 7/Statistik-Ketenagalistrikan-2015-2-pdf.)

Gustriansyah, Rendra. 2017. Analisis Metode Single Exponential Smoothing dengan Brown Exponential Smoothing pada Studi Kasus Memprediksi Kuantiti Penjualan Produk Farmasi di Apotek. Seminar Nasional Teknologi Informasi dan Multimedia 2017, Yogyakarta - Indonesia.

Gustriansyah, Rendra \& Sensuse, Dana \& Ramadhan, Arief. 2017. A sales prediction model adopted the recency-frequency-monetary concept. Indonesian Journal of Electrical Engineering and Computer Science. 6. 711-720. 10.11591/ijeecs.v6.i3.pp711720.

Nurjanah, Ikha. Prakiraan Kebutuhan Energi Listrik Tahun 2016 - 2020 pada PT. PLN (Persero) Unit Area Pelayanan dan Jaringan (APJ) Tegal dengan Metode Gabungan. 